\title{
SPECIATION IN THE MALAY PENINSULA IN RELATION TO DIPTEROCARP FOREST HEIGHT, STRUCTURE, TURNOVER, AND REPRODUCTIVE BIOLOGY
}

\author{
Ng FSP*, Zubir I, Zurfatiha Z, Sharma DSK, Latiff A, Hazrina Z, Shahira A \& Shah- \\ Redza H \\ Perak State Parks Corporation, Kompleks Pejabat Kerajaan Negeri, Jalan Sultan Abdul Aziz, 33300 Gerik, Perak \\ *tropicalplantman@gmail.com
}

Submitted June 2021; accepted October 2021

\begin{abstract}
The Malay Archipelago, also known as Malesia, is customarily divided into nine ecogeographical regions. In any comparison between these regions, Borneo usually stands out with the highest number of species, but if the number of species is divided by land area to obtain a regional species intensity index, the Malay Peninsula stands out prominently, not only for plants but also for mammals, reptiles, amphibians and fish. This striking pattern across the taxonomic spectrum suggests that the forces driving speciation have been more intense in the Malay Peninsula than in other regions of the Archipelago. The Malay Peninsula also stands out in comparison with countries in continental SouthEast Asia. Possible contributory factors to the intensity of speciation may be the height and structure of dipterocarp forests, the rate of tree turnover and the phenomenon of mass flowering.
\end{abstract}

Keywords: Tropical rain forest, species richness, tropical biodiversity

\section{INTRODUGTION}

\section{The concept of regional species intensity (RSI)}

Tropical rain forests are estimated to house over $50 \%$ of the world's terrestrial species although occupying less than $10 \%$ of the world's terrestrial area. This indicates that the forces driving speciation are much more intense under humid tropical conditions than under other climatic conditions. However, within the humid tropics, there are vast differences in biodiversity between regions, indicating that the forces driving speciation vary greatly between humid tropical regions.

Scientists have divided the Malay Archipelago or Malesia into nine ecogeographical regions, which are, from smallest to largest: Moluccas, Lesser Sunda Islands, Malay Peninsula, Java, Sulawesi, Philippines, Sumatra, Borneo, and New Guinea. Information on the distribution of plants and animals in the Archipelago have customarily been documented with respect to these nine regions. For example, in the family Dipterocarpaceae, there are 267 species in Borneo, 158 in the Malay Peninsula, 106 in
Sumatra, and 10 in Java (Table 1). In most cases, Borneo tops the list in number of species for all families of plants and classes of animals. However, if the number of species in a region is divided by the land area of the region to obtain a regional species intensity index (RSI index), the pattern changes dramatically, with the Malay Peninsula standing prominently above the other regions.

The regional species intensity of plants in the Malay Archipelago

The distribution of species in the family Dipterocarpaceae is provided in the Flora Malesiana monograph by Ashton (1982). The RSI index for the Malay Peninsula is 3.4 times that of Borneo and 5.5 times that of Sumatra. The high RSI index for dipterocarps in the Malay Peninsula is repeated for most other plant families (Tables 1-3).

In the family Apocynaceae (subfamilies Rauvolfioideae and Apocynoideae) monographed by Middleton (2007), and in the family Nepenthaceae, monographed by Cheek and Jebb (2001), the Malay Peninsula 
is at the top in regional species intensity. In the family Moraceae (Berg \& Corner 2005, Berg et al. 2006) for the genera Ficus and Artocarpus, the Moluccas tops the list, but the Malay Peninsula is second. In the family Myristicaceae (de Wilde 2000), for Knema and Horsfieldia, the Malay Peninsula tops the list but for Myristica, the Philippines is on top, with Malay Peninsula second.

The leading position of the Malay Peninsula for plants is confirmed by data in the world database on vascular plants for the families Arecaceae (palms), Orchidaceae, Melastomataceae, Zingiberaceae, Gesneriaceae and all vascular plants (Table 3) using "Plants of the World Online" of the Royal Botanic Gardens, Kew (http://www.plantsoftheworldonline.org/).
The Malay Peninsula stands out at the top in RSI index for most of the big iconic tropical families and for all vascular plants taken together. The Malay Peninsula also stands out in comparison with countries in mainland South-East Asia.

\section{The distribution of vertebrates in South-East Asia}

We examined the distribution of vertebrates in South-East Asia using data from IUCN Red Lists and other lists available on the Internet. The data show that the Malay Peninsula is at the apex of the RSI indices except for birds, in which the Malay Peninsula ranks third. The sources of data used in compiling Table 4 are given in the Appendix.

Table 1 Distribution of Dipterocarpaceae, Apocynaceae and Nepenthaceae in Malesia

\begin{tabular}{|c|c|c|c|c|c|c|c|}
\hline \multirow{2}{*}{ Region } & \multirow{2}{*}{$\begin{array}{c}\text { Land area } \\
\text { (in '000 } \\
\mathrm{km}^{2} \text { ) }\end{array}$} & \multicolumn{2}{|c|}{ Dipterocarpaceae } & \multicolumn{2}{|c|}{ Apocynaceae } & \multicolumn{2}{|c|}{ Nepenthaceae } \\
\hline & & $\begin{array}{l}\text { No. of } \\
\text { species }\end{array}$ & RSI index & $\begin{array}{l}\text { No. of } \\
\text { species }\end{array}$ & RSI index & $\begin{array}{c}\text { No of } \\
\text { species }\end{array}$ & RSI index \\
\hline Moluccas & 55 & 6 & 0.11 & 45 & 0.82 & 3 & 0.05 \\
\hline Lesser Sunda Islands & 92 & 3 & 0.03 & 29 & 0.32 & 0 & 0.00 \\
\hline Malay Peninsula & 133 & 158 & 1.18 & 110 & 0.83 & 11 & 0.08 \\
\hline Java & 149 & 10 & 0.07 & 49 & 0.33 & 2 & 0.01 \\
\hline Sulawesi & 193 & 7 & 0.04 & 50 & 0.26 & 8 & 0.02 \\
\hline Philippines & 300 & 50 & 0.17 & 73 & 0.24 & 12 & 0.04 \\
\hline Sumatra & 473 & 106 & 0.22 & 78 & 0.17 & 32 & 0.07 \\
\hline Borneo & 748 & 267 & 0.36 & 101 & 0.14 & 35 & 0.05 \\
\hline New Guinea & 786 & 15 & 0.02 & 102 & 0.13 & 11 & 0.01 \\
\hline
\end{tabular}

RSI index = regional species intensity index

Table 2 Distribution of Ficus and Artocarpus (Moraceae) and Knema, Horsfieldia and Myristica (Myristicaceae) in Malesia

\begin{tabular}{|c|c|c|c|c|c|c|c|c|c|c|c|}
\hline \multirow[b]{2}{*}{ Region } & \multirow{2}{*}{$\begin{array}{l}\text { Land } \\
\text { area } \\
\left({ }^{\prime} 000\right. \\
\left.\mathrm{km}^{2}\right)\end{array}$} & \multicolumn{2}{|c|}{ Ficus } & \multicolumn{2}{|c|}{ Artocarpus } & \multicolumn{2}{|c|}{ Knema } & \multicolumn{2}{|c|}{ Horsfieldia } & \multicolumn{2}{|c|}{ Myristica } \\
\hline & & $\begin{array}{l}\text { No. of } \\
\text { species }\end{array}$ & $\begin{array}{c}\text { RSI } \\
\text { index }\end{array}$ & $\begin{array}{l}\text { No. of } \\
\text { species }\end{array}$ & $\begin{array}{c}\text { RSI } \\
\text { index }\end{array}$ & $\begin{array}{l}\text { No. of } \\
\text { species }\end{array}$ & $\begin{array}{c}\text { RSI } \\
\text { index }\end{array}$ & $\begin{array}{l}\text { No. of } \\
\text { species }\end{array}$ & $\begin{array}{c}\text { RSI } \\
\text { index }\end{array}$ & $\begin{array}{l}\text { No. of } \\
\text { species }\end{array}$ & $\begin{array}{c}\text { RSI } \\
\text { index }\end{array}$ \\
\hline Moluccas & 55 & 79 & 1.44 & 7 & 0.13 & 2 & 0.03 & 10 & 0.13 & 20 & 0.04 \\
\hline Lesser Sunda & 92 & 34 & 0.37 & 4 & 0.04 & 3 & 0.03 & 0 & 0.00 & 3 & 0.03 \\
\hline $\begin{array}{l}\text { Malay Penin- } \\
\text { sula }\end{array}$ & 133 & 99 & 0.74 & 11 & 0.08 & 27 & 0.20 & 25 & 0.19 & 12 & 0.09 \\
\hline Java & 149 & 74 & 0.50 & 5 & 0.03 & 5 & 0.03 & 2 & 0.01 & 2 & 0.01 \\
\hline Sulawesi & 193 & 78 & 0.40 & 5 & 0.03 & 4 & 0.02 & 5 & 0.03 & 8 & 0.04 \\
\hline Philippines & 300 & 87 & 0.29 & 11 & 0.04 & 10 & 0.03 & 6 & 0.02 & 20 & 0.15 \\
\hline Sumatra & 473 & 94 & 0.20 & 12 & 0.03 & 22 & 0.05 & 25 & 0.05 & 11 & 0.02 \\
\hline Borneo & 748 & 138 & 0.18 & 22 & 0.03 & 52 & 0.07 & 44 & 0.06 & 20 & 0.03 \\
\hline New Guinea & 786 & 139 & 0.18 & 5 & 0.01 & 1 & 0.00 & 32 & 0.04 & 99 & 0.13 \\
\hline
\end{tabular}




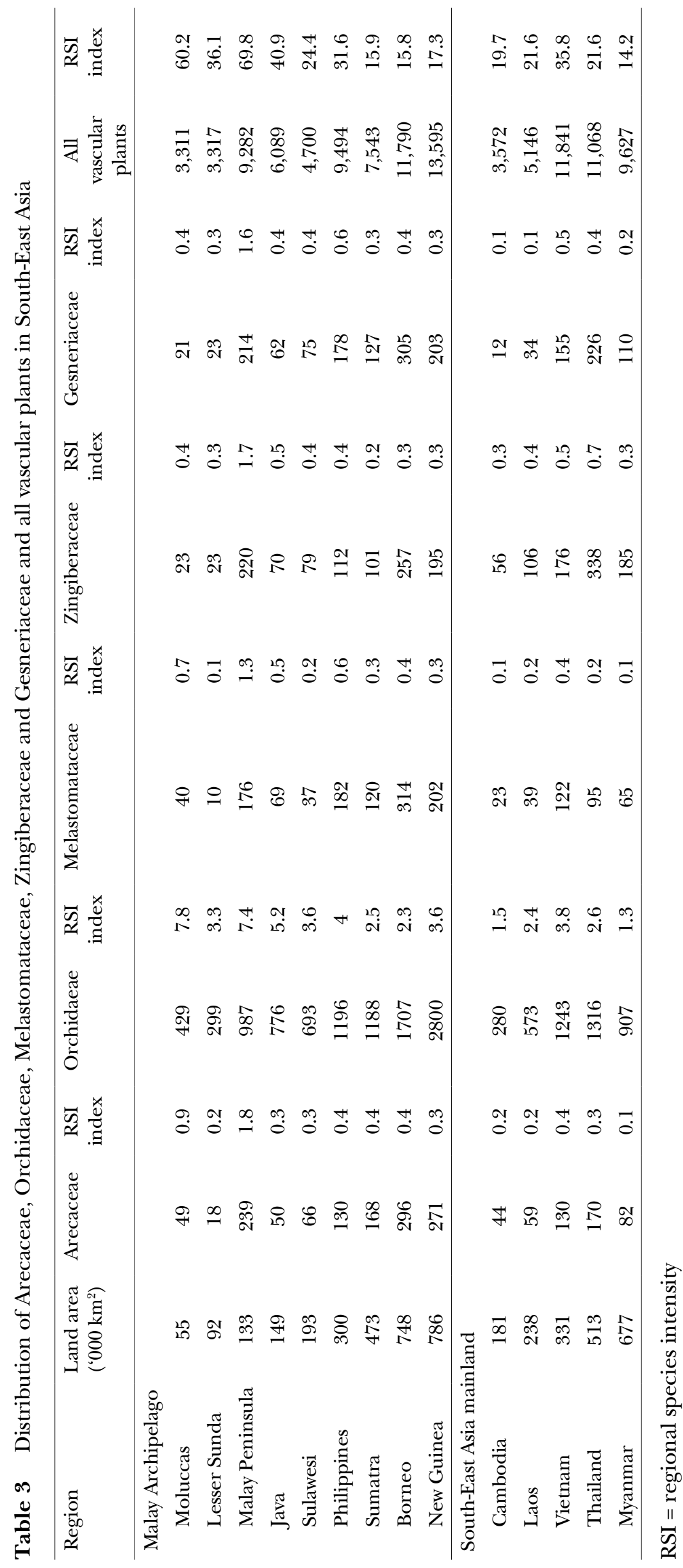




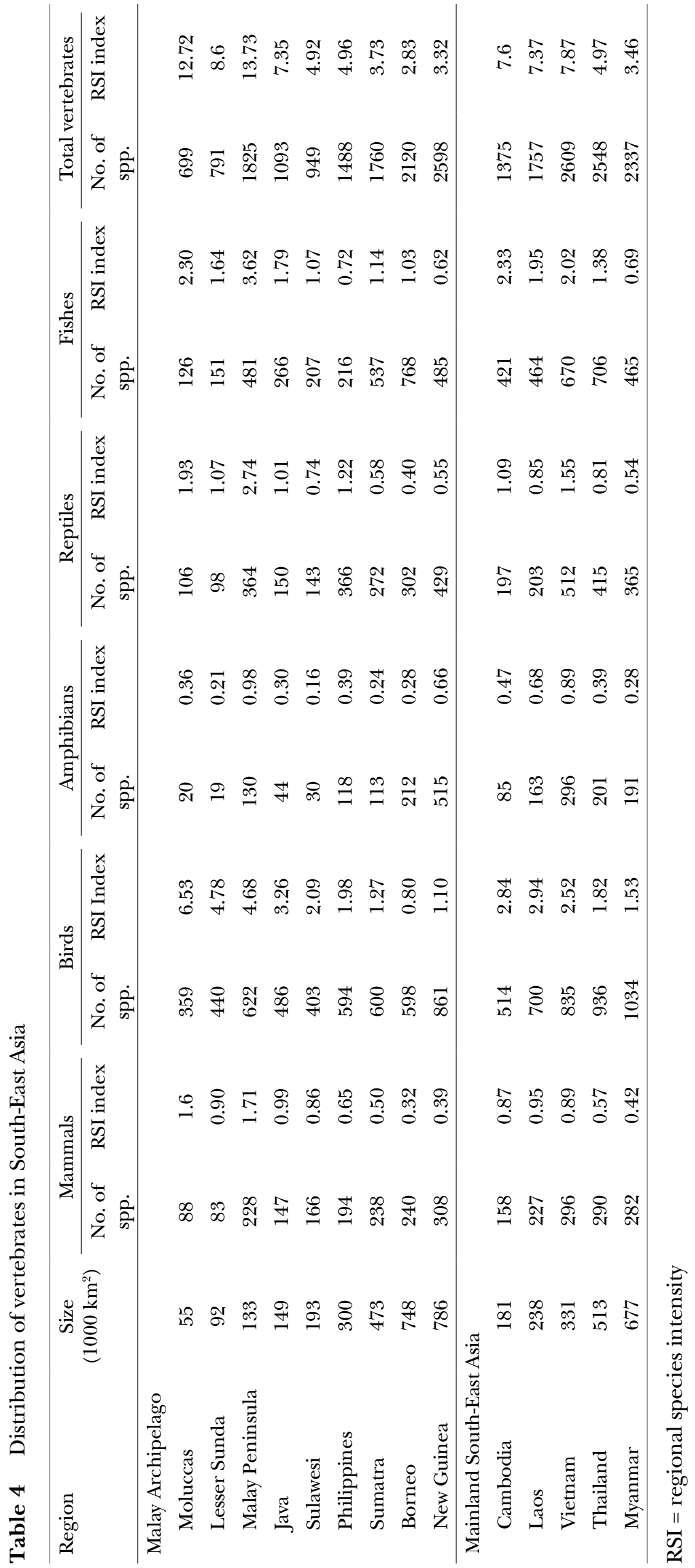


The relation between number of species and land area

In the work by MacArthur and Wilson (1967) on island biogeography, the number of species has been shown to be the result of equilibrium between immigration and extinction, and the number of species tends to increase with the size of the island. This theory does not account for in-situ multiplication of species. The nine regions in the Malay Archipelago and the countries of mainland South-East Asia each have large numbers of endemic species which, because they are found nowhere else, would have arisen in situ. In the Malay Peninsula, 746 species out of 2830 species of trees, or $26 \%$ are endemic ( $\mathrm{Ng}$ et al. 1990). Endemics are not immigrants; hence the theory of island biogeography is not useful for explaining the distribution of species in the nine ecogeographical regions of the Malay Archipelago. There is a trend for the number of species to increase with the land area, but the Malay Peninsula sticks out prominently against this trend.

\section{The mechanisms of speciation}

It is generally agreed that for one species to become two, its population has to be split into two reproductively isolated subpopulations that can evolve separately. Tectonic movements that split land masses and uplift mountain ranges, and major climate changes that raise and lower sea levels would certainly divide populations into separated subpopulations and promote allopatric speciation but the magnitude and time span of geological changes are out of proportion with the number of species in the Malay Peninsula where there are the 190 species of Syzygium, 90 species of Ficus, 70 species of Diospyros, 27 species of Knema, etc. within the small area of the Peninsula. Genetic accidents like the chance doubling of chromosomes to produce tetraploid individuals would reproductively isolate them from their diploid kin and allow them to found new species by sympatric speciation, but after decades of chromosome-counting, it has become apparent that polyploidy is not the answer.

In the following discussion, we draw attention to some features of the forests of the
Malay Peninsula that may have contributed to its high intensity of speciation.

\section{Influence of forest height and dipterocarps on speciation}

Gliding vertebrates are most diverse in the tropical rain forests of South-East Asia but are poorly represented in the tropical rain forests of Africa and America. It has been suggested by Dudley and De Vries (1990), that the greater height of forests in South-East Asia, due to dominance of the family Dipterocarpaceae, may have contributed to the evolution of gliding vertebrates in South-East Asia. Among the most iconic gliding vertebrates are the following, which are all found in the Malay Peninsula: flying snake (Chrysopelea paradisi), Kuhl's flying gecko (Gekko kuhlii), gliding lizard (Draco sumatranus), Sunda flying lemur (colugo) (Galeopterus variegatus), red giant flying squirrel (Petaurista petaurista), Horsfield's flying squirrel (Iomys horsfieldii) and Wallace's flying frog (Rhacophorus nigropalmatus).

There are five species of gliding snakes, all of the genus Chrysopelea, found from India to South China and throughout the Malay Archipelago. Three of the five are found in the Malay Peninsula, viz. the ornate flying snake, $C$. ornata, the paradise flying snake $C$. paradisi and the banded flying snake $C$. pelias. Of flying geckos there are 25 species, all in South-East Asian rain forests, in the genus Gekko (Ptychozoon). The best known ones in the Malay Peninsula are Kuhl's flying gecko, $G$. kuhlii and Horsfield's flying gecko G. horsfieldii. Flying lizards belong to the genus Draco of which there are 42 species, all in South and South-East Asia. In the Malay Peninsula there the common flying lizard, D. sumatranus, the crested flying lizard, D. frimbriatus and the common flying dragon $D$. volens.

There are two species of flying lemurs or colugos. The Sunda flying lemur Galeopteris variegatus has a wide distribution in South-East Asia from Laos, Vietnam and Thailand and south to Bali. It is replaced in the Philippines by Cyanocephalus volans. Videos of colugos in flight show that they can glide upwards and gain height as they glide. Of the flying squirrels there are about 51 species in 15 genera. About 40 species are in South-East Asia while 10 are found from Northern Europe to 
China and North America and 3 in Africa. The best-known species in the Malay Peninsula are the red giant flying squirrel $(P$. petaurista) and Horsfield's flying squirrel (I. horsfieldii).

Of the amphibians, there is little information on how many species are able to glide, but the best known is Wallace's flying frog, Rhacophorus nigropalmatus, which was the first flying frog to be described, by Alfred Russel Wallace in his classic book, The Malay Archipelago. This frog is found in the forests of the Malay Peninsula and Borneo.

Accurate measurements of tree height are extremely rare; hence we were pleased to have discovered a set of measurements in the diaries of FW Foxworthy that have recently been published ( $\mathrm{Ng}$ 2018). Foxworthy was the Forest Research Officer in what was then British Malaya, covering most of the Malay Peninsula. The height measurements were made in February 1923. Foxworthy had arranged for eight canopy trees in a lowland primary forest (Sungai Buloh Forest Reserve) to be felled, carefully cut into $10 \mathrm{ft} \operatorname{logs}$ and laid out on the ground so that he could make precise measurements of tree height, height of clear bole, and diameter at $10 \mathrm{ft}$ intervals (to measure the degree of taper). Six of the trees (Dipterocarpus and Shorea) belonged to the family Dipterocarpaceae and the other two were Durio oxleyanus (Bombacaceae) and Dyera costulata (Apocynaceae). His data, summarised in Table 5, show that the trees ranged in height from 115 to $166 \mathrm{ft}$. The clear bole height, which is the height of the trunk up to first branch (limb) of the crown was mostly $60-90 \mathrm{ft}$ or 20 $30 \mathrm{~m}$. These figures capture the main features of the canopy trees in the Malay Peninsula, in that they are about $50 \mathrm{~m}$ tall, with their clear boles 20-30 m high.

Dipterocarps make up 60-90\% of timbersized trees in the Malay Peninsula, Borneo and Philippines (Foxworthy 1927). They are so dominant in the Malay Peninsula from sea level to about $1500 \mathrm{~m}$ elevation, that the forests of the Peninsula between these two elevations are referred to as dipterocarp forests (Symington 1941). The dipterocarp RSI index of 1.22 for the Malay Peninsula is far above the values of 0.36 for Borneo, 0.22 for Sumatra and 0.17 for the Philippines. The Dipterocarpaceae is believed to have originated in Africa, and spread into India before reaching the Malay Archipelago (Ashton et al. 2021). The high RSI suggests that the family may have been in Malay Peninsula for a long period of evolutionary time and developed its outstanding features before reaching Borneo and Sumatra.

The tallest angiosperm tree in world is a dipterocarp, Shorea faguetiana, found in Sabah and the Malay Peninsula (Ashton 1982), of which the tallest specimen, Menara, was measured in the Danum Valley Conservation Area of Sabah at $100.8 \mathrm{~m}$ tall (article by Gagen M for National Geographic Society, April 3, 2019). This is exceeded in height

Table 5 Measurements of canopy trees in a lowland forest in the Malay Peninsula

\begin{tabular}{|c|c|c|c|c|c|}
\hline Species & Local name & $\begin{array}{l}\text { Total } \\
\text { height }\end{array}$ & $\begin{array}{l}\text { Height to first branch } \\
\text { of the crown (clear } \\
\text { bole height) }\end{array}$ & Taper & $\begin{array}{l}\text { Diameter } \\
\text { above stump }\end{array}$ \\
\hline Dipterocarpus scortechinii & Keruing bulu & $148 \mathrm{ft} 8 \mathrm{in}$ & $111 \mathrm{ft}(33.8 \mathrm{~m})$ & 1 in in $9.3 \mathrm{ft}$ & 29.75 in \\
\hline Durio oxleyanus & Durian daun & $143 \mathrm{ft} 6$ in & $77 \mathrm{ft} 6$ in $(23.6 \mathrm{~m})$ & 1 in in $22.8 \mathrm{ft}$ & 23.05 in \\
\hline Dyera costulata & Jelutong & $166 \mathrm{ft} 1 \mathrm{in}$ & $96 \mathrm{ft} 10 \mathrm{in}(29.49 \mathrm{~m})$ & 1 in in $10.3 \mathrm{ft}$ & $46.25 \mathrm{in}$ \\
\hline Shorea acuminata & $\begin{array}{l}\text { Meranti rambai } \\
\text { daun }\end{array}$ & $115 \mathrm{ft} 9$ in & $57 \mathrm{ft} 9$ in $(17.5 \mathrm{~m})$ & 1 in in $10.2 \mathrm{ft}$ & $26.65 \mathrm{in}$ \\
\hline Shorea kunstleri & Meranti pa'ang & $147 \mathrm{ft} 3$ in & $82 \mathrm{ft} 3$ in $(25.1 \mathrm{~m})$ & 1 in in $10.2 \mathrm{ft}$ & 33.35 in \\
\hline Shorea leprosula & $\begin{array}{l}\text { Meranti } \\
\text { tembaga }\end{array}$ & $164 \mathrm{ft} 9$ in & $80 \mathrm{ft}(24.4 \mathrm{~m})$ & 1 in in $16.7 \mathrm{ft}$ & 32.2 in \\
\hline Shorea rigida & Meranti kepong & $157 \mathrm{ft} 11 \mathrm{in}$ & $77 \mathrm{ft}(23.5 \mathrm{~m})$ & 1 in in $7.7 \mathrm{ft}$ & $34.3 \mathrm{in}$ \\
\hline Shorea parvifolia & $\begin{array}{l}\text { Meranti sarang } \\
\text { punai }\end{array}$ & $137 \mathrm{ft} 6$ in & $79 \mathrm{ft} 6$ in $(24.2 \mathrm{~m})$ & 1 in in $10.5 \mathrm{ft}$ & 30.5 in \\
\hline
\end{tabular}


only by the gymnosperm Coast Redwood of California, Sequoia sempervirens, of which the tallest, known as Hyperion, was measured at $115.9 \mathrm{~m}$

African tropical rain forests trees are much shorter, at 30 to $40 \mathrm{~m}$ (Longman \& Jenik 1974). Ong CL (personal communication 2021), a highly experienced forest technician who is familiar with forests in Malaysia and forests in the Republic of Congo (former French Congo), the Democratic Republic of Congo (the former Belgian Congo) and Gabon, says that the forests in those countries have an average clear bole height of 10-15 m whereas the average clear bole height in the Malay Peninsula is $20-30 \mathrm{~m}$. The clear bole height of the dipterocarp forests of the Malay Peninsula is twice that of the forests in the Congo Basin.

For tropical America, there are claims for exceptional groves of trees $80 \mathrm{~m}$ tall (Gorgens et al. 2021) and reports of individual trees $100 \mathrm{~m}$ tall but there are no indications that the Amazon forests are on average taller than the dipterocarp forests of the Malay Peninsula.

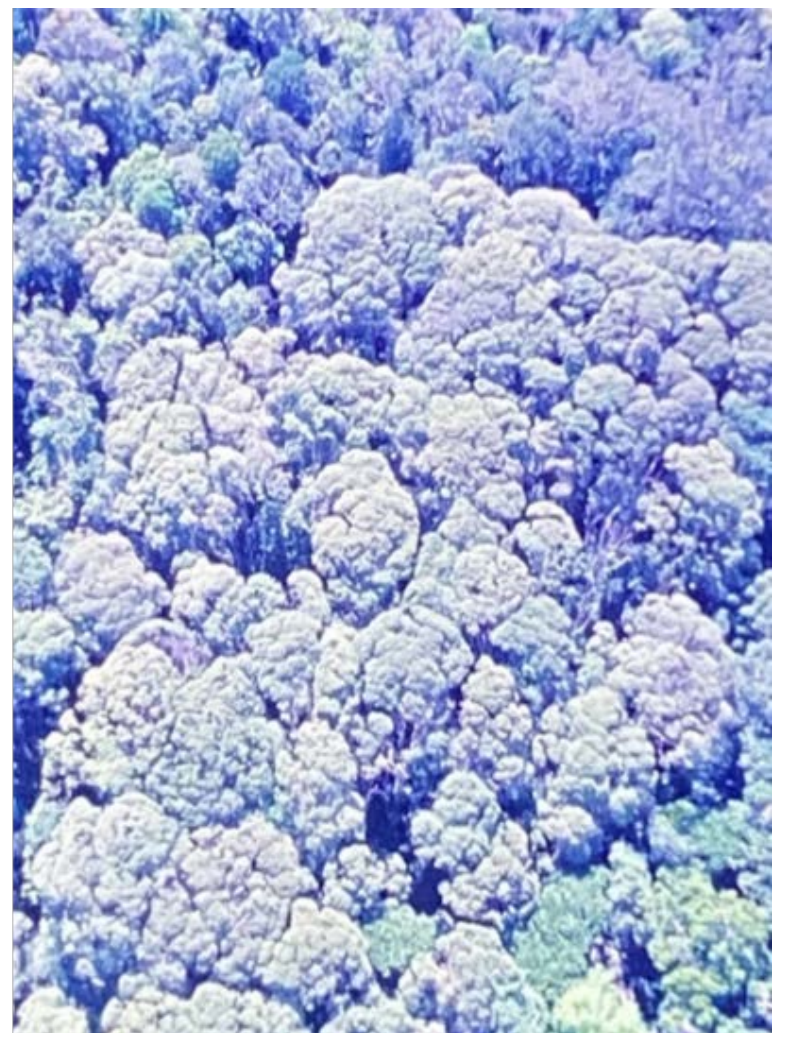

Figure 1 Canopy of dipterocarp forest seen from above

\section{Possible influence of forest structure on speciation}

The main driver for the development of gliding may not be the height of the trees but another feature of the dipterocarp forests, which is the crown-shy phenomenon, whereby the crowns of adjacent trees maintain a clear space between themselves. This gives to the dipterocarp forests a characteristic appearance like closely packed heads of cauliflowers when viewed from above (Figure 1). It had been assumed that the crowns were in close contact with each other until $\mathrm{Ng}$ (1977b) published pictures of dipterocarp crowns from below, showing clear sky between adjacent crowns (Figure 2). Crown shyness had not been noticed before because the understorey vegetation obscures the view of the canopy from below. It has become evident from subsequent observations that crown shyness is exhibited by practically all canopy species in the dipterocarp forests regardless of the families they belong to. Since the crowns are separated from each other,

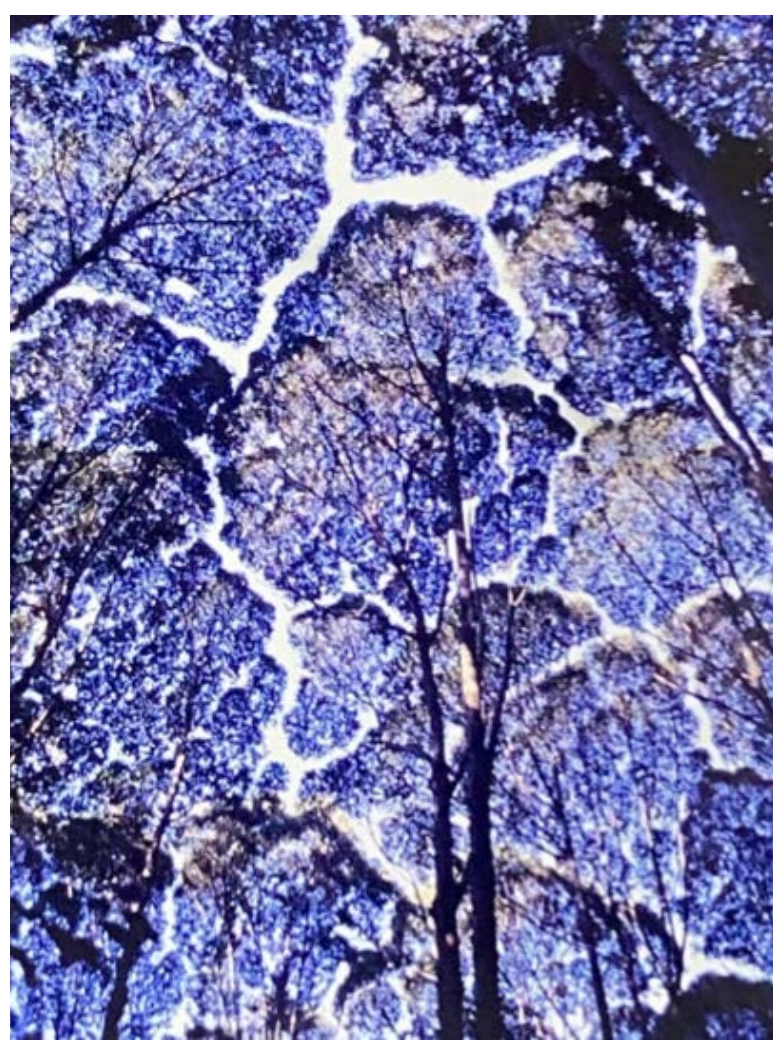

Figure 2 Canopy of dipterocarp forest seen from below with understorey removed, showing separate crowns which are themselves breaking up into crownlets 
animals have to fly, leap, swing or glide in order to move from tree to tree. As the crowns get older, they separate into crownlets. Crown shyness is correlated with abrasion as adjacent trees brush against each other in the wind (Putz et al. 1984). Tall trees would sway more than short trees. Since the forests in the Congo are only half as tall as dipterocarp forests, the degree of crown shyness should be much less and may be negligible. This needs to be confirmed by observers who know what to look for. Crown shyness in the dipterocarp forests also means that more light comes through the canopy. Combined with the greater height of dipterocarp trees and the greater volume of space under the canopy, the conditions for the evolution of understorey species would be greatly increased.

The height of dipterocarp trees is correlated with the ability to develop a tall single leader shoot during an extended juvenile phase lasting 20 years or longer. This ability is so strongly expressed that whenever the juvenile leader shoot is damaged, a new single leader is produced which restores the dominance of a single vertical leader shoot ( $\mathrm{Ng} \mathrm{1976).} \mathrm{The}$ branches are thin and temporary and are shed when the tree reaches the canopy and develops a mature crown. This change from juvenile to mature form was first described by Halle and $\mathrm{Ng}$ (1981) as a metamorphosis. The branches that are produced after metamorphosis are different in form and function from the branches before metamorphosis. The branches after metamorphosis are able to thicken and compete with the leader (Figure 3), unlike those of the juvenile stage. Hence, it is useful to call them limbs instead of branches. Limbs are of equal status with the original leader and with each other. Limbs do not get shed, but they break off when they get too large and heavy. The clear bole of the timber industry is the log length from ground level to the first limb of the mature crown. Where the limbs break off, they provide potential places for large holes to form in which large hornbills can make their nests.

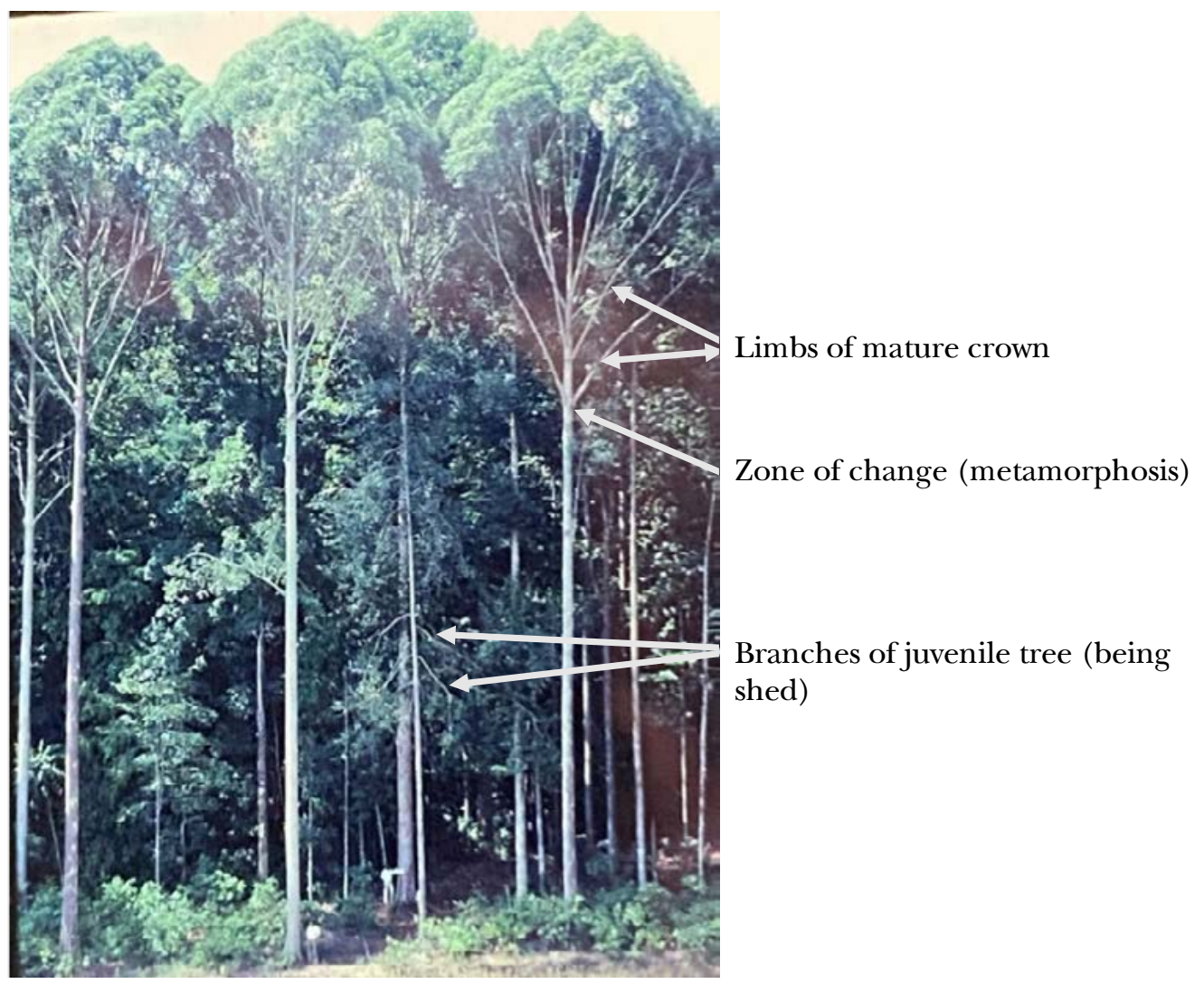

Figure 3 Comparison of juvenile pole-like trees with thin branches in the process of being shed, with maturing trees bearing permanent limbs on clear boles 


\section{Trees provide surfaces for the evolution of epiphytes}

The role of trees in providing surfaces for epiphytes was the subject of a study by Henderson (1938) in which he examined the vascular epiphytes on several trees of Dipterocarpus oblongifolius growing on a riverbank in the Taman Negara National Park of the Malay Peninsula. He found 129 species, of which 87 species were orchids. Henderson also made a study on the epiphytic orchids on two trees of Saraca bijuga growing in the same locality as $D$. oblongifolius and found 15 species of which only 2 species of orchids were common to D. oblongifolius and $S$. bijuga, indicating a high degree of hostepiphyte specialisation.

\section{Rate of turnover of trees}

Another contributory factor to speciation could be the rate of turnover of trees. Tree life spans are poorly understood and tree deaths are usually attributed to disease, pest, lightning and storm damage. However, trees in dipterocarp forests of all families except Apocynaceae, develop heart rot which weakens the trunk from the inside and shortens the life of trees.

The living wood of most trees is a peripheral zone of living sapwood, below which is dead, but chemically-protected, heartwood. However, chemical protection breaks down with the passage of time ( $\mathrm{Ng}$ 2013). In SouthEast Asia, the most durable woods are known to have a useful life of 100 years under exposed conditions before their chemical protection breaks down. Within a living tree, even the most durable heartwood could start to decay in the centre after 100 years. A big old tree with the most durable heartwood would have a wall made up of 100 years of solid wood around a decayed core that increases in size even as the tree grows in diameter, until its internal hole gets too big for the peripheral band of solid wood to support it and such trees will collapse in a storm. Such heavy hardwood trees may live to 300 years but they belong to only about 10 genera in the Malay Peninsula. The majority of trees are medium or light hardwoods that will develop heart rot earlier. In decay, trees provide resources for a vast range of organisms that live on the breakdown of wood. Figure 4 shows logs at a sawmill that illustrate the pervasiveness of heart rot in trees of dipterocarp forests.

According to Ong CL (personal communication) heart rot is rare among trees in the Congo. We have no information on heart rot in tropical America. The high occurrence of heart rot in the dipterocarp forests suggests not only that the life span of trees is much shorter in the dipterocarp forests than other forests but also that dipterocarp forests sustain a vast ecosystem of organisms involved in the process of breakdown.

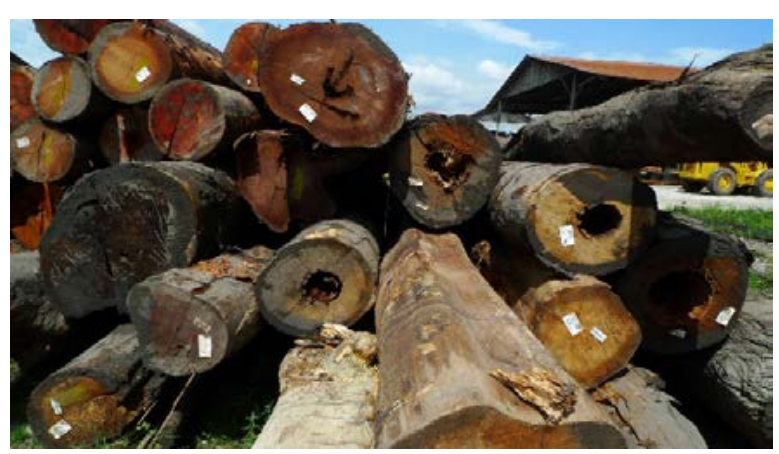

Figure 4 A log-yard showing extent of heart rot (Ng 2013)

\section{Mass flowering and mast fruiting}

If it requires some kind of recurrent reproductive upheaval to facilitate speciation, there is one good candidate, which is the phenomenon of mass flowering (reviewed by $\mathrm{Ng}$ 1977a, Ghazoul 2016) followed by mast fruiting. Mast fruiting is an old English word referring to periods of very intensive production of acorns observed in oak forests in Europe. Mast fruiting in dipterocarp forests refers to the very intensive fruiting of dipterocarp forests, but hundreds of different species of different genera and families are involved, not just oaks (of which there are many species in Malaysia), and not just dipterocarps. In most years, the flowering and fruiting of trees is reduced to a small trickle distributed throughout the year. In a mass-flowering event, trees of many species, of different genera and families, come into flower at about the same time, usually between March and May. This is followed by mast fruiting, spread out over 1 to 9 months because the many different species require different lengths of time for fruit development ( $\mathrm{Ng} \&$ Loh 1974). The forest floor gets carpeted 
with seedlings. The abundance of flowers, fruits, seeds and seedlings created as a result of a mass-flowering event results in a glut of food for animals for about 9 months, followed by a succession of lean years. Mass flowering followed by mast fruiting is well documented in the Malay Peninsula and Sabah in the northern part of Borneo but not mentioned elsewhere.

\section{The significance of endemic species}

The rarest of species in the tropics are represented by single specimens in a museum or herbarium, and taxonomists make a lot of effort to locate more specimens, usually without success. The default explanation is that such species are the last of their species, on the way to extinction. There is an alternative explanation that they are newly emergent species.

Where a rare species is located within the area of a common species of the same genus, e.g. Dysoxylum frimensis (Ng 2021) embedded in the area of D. arborescens and Rafflesia tiomanensis (Siti-Munirah 2021) embedded in the area of $R$. cantleyi, the rare endemic species may be new species just emerging or old ones on the way out. The study of such pairs of rare and common species may offer clues about the mechanisms of speciation and extinction in the tropics.

\section{AGKNOWLEDGEMENTS}

We thank PS Ashton and Lord Gathorne Cranbrook for their comments on the draft of this paper.

\section{REFERENCES}

Ashton PS. 1982. Dipterocarpaceae. Flora Malesiana. Volume 9. Nationaal Herbarium Nederland, Leiden.

Ashton PS, Morley R J, Heckenhauer J \& Prasad V. 2021. The magnificent dipterocarps: précis for an epitaph? Kew Bulletin 76: 87-125. doi 10.1007/ S12225-021-09934-7

Berg CG \& Corner EJH. 2005. Moraceae-Ficus. Flora Malesiana. Volume 17. Part 2. Nationaal Herbarium Nederland, Leiden.

Berg CC, Corner EJH \& Jarrett FM. 2006. Moraceae (genera other than Ficus). Flora Malesiana. Volume
17. Part 1. Nationaal Herbarium Nederland, Leiden.

Снеек M \& Jевв M. 2001. Nepenthaceae. Flora Malesiana. Volume 15. Nationaal Herbarium Nederland, Leiden.

DE WILdE WJJO. 2000. Myristicaceae. Flora Malesiana. Volume 14. Nationaal Herbarium Nederland, Leiden.

Dudley R. \& De VRies P. 1990. Tropical rain forest structure and the geographical distribution of gliding vertebrates. Biotropica 22: 432-434.

Foxworthy FW. 1927. Commercial Timber Trees of the Malay Peninsula. Forest Department, Kuala Lumpur.

GHAzoul J. 2016. Dipterocarp Biology Ecology and Conservation. Oxford University Press, Oxford.

Gorgens EB, Nunes MH, Jackson T et AL. 2021. Resource availability and disturbance shape maximum tree height across the Amazon. Global Change Biology 27: 177-189. https://doi.org/10.1111/gcb.15423

HaLle F \& NG FSP. 1981. Crown construction in mature dipterocarp trees. Malaysian Forester 44: 197-221.

HENDERSON MR. 1938. The epiphytic flora of Dipterocarpus oblongifolius. Gardens' Bulletin Singapore 9: 93-97.

Longman KA \& JenIK J. 1974. Tropical Forests and Its Environment. Longman, London.

Middleton DJ. 2007. Apocynaceae (subfamilies Raufolfioideae and Apocynoideae). Flora Malesiana. Volume 18. Nationaal Herbarium Nederland, Leiden.

MacArthur R \& Wilson EO. 1967. The Theory of Island Biogeography. Princeton University Press, Princeton.

NG FSP. 1976. Responses to leader shoot injury in Shorea platyclados. Malayan Forester 39: 91-100.

NG FSP. 1977a. Gregarious flowering in dipterocarps in Kepong 1976. Malayan Forester 40: 126-137.

NG FSP. 1977b. Shyness in trees. Nature Malaysiana 2: 340-37.

NG FSP. 2013. Age of trees in tropical rainforests estimated by timing of wood decay. Journal of Tropical Forest Science 25: 437-441.

NG FSP. 2018. Diaries of FW Foxworthy, Malaysia's First Forest Research Officer. Forest Research Institute Malaysia. Kepong.

NG FSP. 2021. Dysoxylum frimensis, an incredible new species. Journal of Tropical Forest Science 33: 286289. https://doi.org/10.26525/jtfs2021.33.3.386

NG FSP \& LoH HS. 1974. Flowering to fruiting periods of Malaysian trees. Malayan Forester 37: 127-132.

NG FSP, Low CM \& MAT AsRi 1990. Endemic Trees of the Malay Peninsula. Forest Research Institute, Kepong.

POWO 2019. Plants of the World Online. Facilitated by the Royal Botanic Gardens, Kew. http://www. plantsoftheworldonline.org/ Retrieved 24 June 2021.

Putz FE, Parker GG \& Archibald RM. 1984. Mechanical abrasion and intercrown spacing. The American Midland Naturalist 112: 24-28.

Siti-Munirah MY, Salmah A \& Razelan MS 2011. Rafflesia tiomanensis (Rafflesiaceae) a new species from Pulau Tioman, Pahang, Malaysia. Malayan Nature Journal 73: 19-26.

Symington CF. 1941. Foresters' Manual of Dipterocarps. Forest Department, Kuala Lumpur. 
Appendix Sources of data on vertebrates (excluding totally marine, vagrant and introduced species and those of uncertain occurrence and uncertain origin)

\section{Mammals}

IUCN Red List of Threatened Species. Version 2021-1. https://www.iucnredlist.org. Each species was analysed by geographic range using range map and notes available in each species assessment page.

\section{Birds}

BirdLife International (2021) IUCN Red List for birds: http://www.birdlife.org on year 2021. The IUCN Red List of Threatened Species. Version 2021-1. <https://www.iucnredlist.org> Birdlife International Datazone website, http://datazone. birdlife.org/country. Each species was analysed by geographic range using range map and notes available in each species information page.

\section{Amphibians}

Frost DR. 2021. Amphibian Species of the World: an Online Reference. Version 6.1 (2021) accessible at https://amphibiansoftheworld.amnh.org/ index.php. American Museum of Natural History, New York, USA. doi.org/10.5531/db.vz.0001.
IUCN 2021. The IUCN Red List of Threatened Species. Version 2021-1. https://www.iucnredlist. org. Each species was analysed by geographic range using distribution notes available in each species information page.

\section{Reptiles}

Uetz P. (ed). The Reptile Database. http://www. reptile-database.org (accessed 2021). Using advance search function on the Reptile Database website at https://reptile-database.reptarium.cz/ advanced_search, each species was analysed by geographic range using distribution notes available in each species information page.

\section{Fishes}

The IUCN Red List of Threatened Species Version 2021-1. https://www.iucnredlist.org. Froese R and Pauly D (eds). 2021. FishBase. World Wide Web electronic publication. www.fishbase.org, version (02/2021). Fishbase website: https://www.fishbase. in/search.php. 